\title{
Beyond cost saving. Other factor consideration in online purchases of used electronic goods: a conjoint analysis approach
}

\author{
Michael Adu KWARTENG \\ Tomas Bata University in Zlín, Zlín, Czech Republic \\ kwarteng@utb.cz \\ Michal PILÍK \\ Tomas Bata University in Zlín, Zlín, Czech Republic \\ pilik@utb.cz \\ Eva JUŘIČKOVÁ \\ Tomas Bata University in Zlín, Zlín, Czech Republic \\ jurickova@utb.cz
}

\begin{abstract}
The market for second-hand and refurbished goods continues to record strong growth in most economies around the world. One obvious motivating factor in consumer choice of second-hand goods is price affordability. However, as the used market evolves, especially with the adoption of online e-commerce platforms, consumers' inclination for used goods have also become complex. This paper investigates other appealing factors beyond price affordability (cost saving) in consumer choice of usable electronic goods. To do this, a consumer preference model was designed to reveal the key factors that drive consumer choices in the used electronic goods market. A case study using an emerging economy (Czech Republic) where used goods outlets are rampant coupled with the propensity for used electronic gadgets. The study adopted a simple random technique geared towards all the regions in the Czech Republic. The aggregate conjoint analysis method was used to model consumer preferences to determine the importance they attach to attributes most considered by consumers in the online used goods transactions. The result indicates that in respect of online purchases of used electronic appliances, a product's 'number of years in use' is the next most important motivating factor after cost saving (price affordability). The study would help give a general insight into consumer preferences in the used electronic goods market.
\end{abstract}

Keywords: used electronic goods, refurbished goods, consumers, Czech Republic, preference modelling, conjoint analysis.

Please cite the article as follows: Kwarteng, M.A., Pilík, M, and Juřičková, E. (2018), "Beyond cost saving. Other factor consideration in online purchases of used electronic goods: a conjoint analysis approach", Management \& Marketing. Challenges for the Knowledge Society, Vol. 13, No. 3, pp. 1051-1063, DOI: 10.2478/mmcks-2018-0022.

\section{Introduction}

In spite of growing global trade restrictions on certain kinds of used goods, the market does not seem to be nearing extinction any time soon (Czaga \& Fliess, 2004). On the contrary, the market for used vehicles and some electronic appliances, in particular, continues to record high annual growths in many countries (Czaga \& Fliess, 2004; Heese et al., 2005; Clerides, 2008; Singh, 2015) around the world. Though international trade of used goods were typically the target destinations of poor under-developed and developing countries, the emergence of several e-commerce platforms (eBay, Amazon, 
Taobao, OLX, Alibaba etc.) has changed the destination dynamics of used goods (Ghose, 2009; Lewis, 2011; Singh, 2015). For instance, Heese et al., (2005) and Ghose (2009) explain a booming intra U.S trade for used vehicles whiles Williams \& Paddock (2003) in a survey explained that $40 \%$ of U.K. consumers had bought various kinds of used goods during the past 12 months of the survey. This affirms the notion that though poor nations are often recipients of used items, there is a growing interest in the trade in the developed world as well for all sorts of reasons. Shevlin (2008) and Austin (2015) further explain that the interest shown in used goods, could partly also be attributed to the emergence of refurbished goods - another form of 'used' goods. Refurbished goods, unlike completely used goods, are products that were once recalled either by the manufacturer or the vendor for various reasons (Shevlin, 2008). These recalled goods are subsequently tested, repaired, remanufactured or reconditioned for further sale (Oraiopoulos, Ferguson, \& Toktay, 2012). Though reasons for a refurbished good are often not disclosed, buyers are tempted to purchase because of its relatively low price, good physical condition and the fact that it has been reconditioned by a certified manufacturer (Kogan, 2011).

In spite of the several factors put forward as reasons for consumer choice, none so far attempts to measure the consumers' relative importance assigned to the various factors as they shop online. Further, there has also not been any attempt at modelling consumer preferences and utilities they consider most when shopping for used products online. Though the work by Guiot \& Roux (2010) identified relevant factors driving the consumers' choice of used goods, no relative importance was assigned to the factors consumers prefer most or least. Moreover, their research was neither specific to online shopping of used goods or to the more definite topic of used electronic appliances considered in this paper. We further argue that given the varied and complex reasons identified as motivating factors influencing the consumers' choice to shop, consumers indirectly make several trade-offs in such choices. In view of this, this paper uses a preference modelling approach (conjoint analysis) to ascertain the utilities/utility consumers assign to the more relevant factors influencing their online shopping of used electronic goods. This is carried out in an environment of trade-off modelling where aggregate utilities assigned by consumers represent their relative weights of importance attached to the relevant factors influencing their choices to shop for used electronic goods. This paper begins on a basic premise of the assumption that the most obvious motivating factor for second-hand goods is first and foremost about cost saving (price). In this regard, the paper investigates the other compelling factors beyond cost saving for consumers of second-hand electronic goods. Using a case study of Czech Republic as an emerging economy where used electronic goods outlet are rampant and visible via online coupled with the respondents' penchant to purchase used electronic goods, the age-long empirical and theoretical gap is filled as far as eliciting the magnitude of factors that consumers' place much premium in the case of used electronic goods are concerned.

The rest of the paper is organized under the following sections. Literature Review, the methodology, data collection, and sampling methods are explained. The results and conclusions of the study are finally presented.

\section{Literature review}

\section{State of the art in online purchases of used goods in the Czech Republic}

The online transactions of goods and services coupled with the used goods market (Pilik et al., 2017) gained traction in the early days of internet penetration in the Czech 
Republic (Kwarteng et al., 2017). However, online customers were adamant to hook up on the internet in search of used goods rather than walking into the local outlet to catch a feel of the good in question. As with other notable or so-called big online websites that deal with the sale of both used and brand new items like the Amazon, eBay's among others. The irony here is that Czechs saw it as a very daunting task to shop online and to buy a solid and exact used good. But as the internet kept springing, it has become necessary for vendors of the used goods market to broaden their horizon with the zeal to publicize their goods online. Evident to this assertion is accrued from the inventory in Table 1. A recent report garnered by Equa Bank (2017) revealed that almost 9 out of 10 Czechs in one way or the other sell second-hand goods online. The report went on to explain that the ordinary Czech buy clothes and other households with more than $500 \mathrm{czk}$ on a single purchase in these second-hand outlets. The most vital rationale behind ordinary Czech's view behind selling his/her second item is stemmed from their traditional notion of not voluntarily throwing things out. Extracts from the survey carried out by Equa Bank (2017) showed that used goods online are becoming rampant in the Czech Republic because of the affordable price tag on such a good in question especially in the case of mobile phones, electrical appliances, and so forth. Almost 93 percent (93\%) of Czechs sell their own second-hand items through online platforms and one-fifth of Czechs are of the view to get rid of unsuitable gifts and, hence, decide to relay it to second-hand online platforms for sale (Equa bank, 2017). Apart from the affordable price tag influencing the patronage of second-hand goods online platforms, it was revealed in the survey that second-hand purchases for children were the bestespecially clothes and sports equipment. - with the indication that when getting such goods, it does not pay to get new ones. Nearly, 43 percent (43\%) of the respondents asserted to this view. Contrary to this perspective by the respondents, is the one that proposes that people will not want to give out money to items that have shorter spun. In this respect, the Czechs are very far-sighted and fear-provoking country, as seconded by the executive director of Equa Bank, Jakub Pavel.

As seen from the Table 1 of inventory taken on used goods traded online on the Czech market, there is an indication of more possible outlets to emerge as time goes on. From the research of Equa Bank (2017), the most famous selling and shopping online platform are Aukro.cz with exactly 33 percent (33\%) of their respondents connecting to that portal for purchase. Similarly, one-third of their respondents buy second-hand goods on other notable online platforms. Some respondents also reiterated their claims by connecting via social media sites (Facebook, LinkedIn, etc.) for their demand for such used goods. According to a report presented by Equa Bank, different millennial age groups shops over the internet for second-hand goods such as books, while ages above 54 are more inclined to their usual brick and mortar style of shopping purposely for goods like antiques and so forth.

On the bases of clarity and significance of the present study, Table 1 presents an inventory of used/ second-hand goods electronic outlets traded online in the Czech Republic, giving an insight into the different regions in the Czech Republic with their kind of used electronic goods traded online, along with their respective websites. It must be emphasized that not all used electronic goods traded online were captured here for deliberations, as was the case for upcoming ones and others that do not provide adequate descriptions on the used goods for customers to make specific inquiries. 
Table 1. Inventory of Used Electronic outlet traded online

\begin{tabular}{|l|l|l|l|}
\hline Name & \multicolumn{1}{|c|}{ Website } & Type of goods & Region \\
\hline $\begin{array}{l}\text { Zdruhé } \\
\text { ruky }\end{array}$ & https://elektro.zdruheruky.cz/ & $\begin{array}{l}\text { All type of goods } \\
\text { including electronic }\end{array}$ & Moravský kraj \\
\hline $\begin{array}{l}\text { Diskontní } \\
\text { nákupy } \\
\text { Otrokovic } \\
\text { e }\end{array}$ & https://www.diskontni-nakupy.cz/ & $\begin{array}{l}\text { home appliance } \\
\text { and all kind of } \\
\text { electronics }\end{array}$ & Zlinský Kraj \\
\hline 2jakost & https://www.2jakost.cz/ & $\begin{array}{l}\text { home appliance, } \\
\text { elektronics, boilers }\end{array}$ & $\begin{array}{l}\text { Borek - České } \\
\text { Budějovice }\end{array}$ \\
\hline OKAY & https://www.okay.cz/maxisleva-rozbaleno/ & $\begin{array}{l}\text { all kind of } \\
\text { electronics, } \\
\text { furniture }\end{array}$ & $\begin{array}{l}\text { Brno Moravský } \\
\text { kraj }\end{array}$ \\
\hline MALL CZ & https://www.mall.cz/listy/bazar & $\begin{array}{l}\text { electronics, sports } \\
\text { equipment }\end{array}$ & $\begin{array}{l}\text { Hlavni město } \\
\text { Praha }\end{array}$ \\
\hline $\begin{array}{l}\text { Bazar } \\
\text { Miloslav } \\
\text { Dundych }\end{array}$ & http://www.bazarliben.cz/ & home appliance & $\begin{array}{l}\text { Hlavni Město } \\
\text { Praha }\end{array}$ \\
\hline $\begin{array}{l}\text { Elektro } \\
\text { Solid }\end{array}$ & http://eshop.elektrosolid.cz/katalog/iijakost- \\
\hline $\begin{array}{l}\text { Damil } \\
\text { elektro }\end{array}$ & http://www.damil.cz/cs/shop/ & Mobile phones & $\begin{array}{l}\text { Hlavni Město } \\
\text { Praha }\end{array}$ \\
\hline
\end{tabular}

Source: Authors' results.

\section{Methodology and data used}

\section{The Conjoint Analysis as a basic method}

The conjoint analysis (CA) method is one of a range of tools in mathematical psychology used to model consumer preferences. The method is particularly useful when respondents are presented with a limited number of attributes and characteristics describing a set of stimuli (products or services). The CA approach helps to indirectly unravel hidden utilities assigned to products and services, particularly in an environment of trade-offs (Green et al., 2001). Over the last three decades, this concept has found an extensive usage in many academic disciplines, specifically, in marketing research. Although the overall machination of CA is attributed to Green \& Rao (1971) and later by Green \& Srinivasan (1978). There are numerous works that have ushered the CA into the mainstream research seen today (Bernoulli, 1954; Simon, 1957; Churchman \& Churchman, 1961; Luce \& Tukey, 1964; Hoffman, 1967; and Fishburn, 1968). The method has been tailored to suit a range of different data types under different circumstances. Such generalizations of the CA method have resulted in other variants aside from the traditional conjoint analysis (TCA). These are choice-based conjoint analysis (CBCA), adaptive conjoint analysis (ACA), and self-explicated conjoint analysis (Rao, 2014). The robustness, accuracy and reliability of CA have been vouched in many test studies (Scott \& Wright, 1976; McCullough \& Best, 1979; Malhotra, 1982; Bryan et al, 2000; Bryan \& Parry, 2002; Afful-Dadzie \& Afful-Dadzie, 2017) - giving a stamp of approval to the widespread use of the conjoint analysis method.

Traditionally, the CA method works by decomposing preference data of respondents and computing part-worth utility values for each level under each attribute. Concurrently, the trade-offs made in the decision-making process can also be examined between the different attribute levels. The result of the modelling assigns 
large part-worth utilities to attribute levels that are most preferred whiles least preferred levels receive small part-worth utilities (Kuhfeld, 2005). The coefficient or part-worth utilities are then summed up to elicit the relative importance decision makers (the respondents) place to the attributes and their levels. In practice, the traditional conjoint analysis (TCA) method as used in this paper, measures CA as a simple-effects analysis of variance (ANOVA) but with a specific set of outputs. This is arithmetically expressed in Eq. (1) indicating an individual respondent's stated preference geared towards a set of attributes measured at various levels is shown.

$$
Y_{c=\mu} \mu+\beta_{c 1} X_{1}+\ldots+\beta_{c k} X_{k}+\ldots+\beta_{c K} X_{K}+\varepsilon_{c}
$$

Where $Y_{c}$ denotes an individual respondent's utility regarding an attribute $\left(X_{k}\right)$ and $\mu$ signifying the general mean. The expression $\beta_{c 1}$ is the coefficient utility for a particular level expressed by an individual respondent and $\varepsilon_{c}$ is the error term. The mathematical implication of the CA method reflecting the combined effect of a selected set of independent variables determined on a dependent variable, the factors (attributes) $\left(X_{k}\right)$ denote the independent variables, the choice (judgments) is the dependent variable $\left(Y_{c}\right)$ whiles the $\beta^{\prime s}$ Represent the part-worth utilities. This in effect signifies the parameter estimates from the ANOVA model (Rao, 2014). Going forward, the total utility of a factor (attribute) determining the value apportioned by the overall respondents' is ascertained by summing up the coefficients or the part-worth utilities of the entire decision makers. With this, Eq. (2) Expresses an additional form of a single respondent's utility $U$ in relation of such attribute, denoted as $\left(X_{k}\right)$.

$$
U\left(A_{i}\right)=\sum_{i=1}^{m} \sum_{j=1}^{m_{j}} \beta_{i j} G_{i j}
$$

Where $\beta_{i j}$ denotes the part-worth utility estimate on the $j$-th level of the $i$-th factor $(i=1,2 \ldots n$ and $j=1,2 \ldots m)$, and $G_{i j}$ Indicates the presence of the $j$-th level of the $i$-th attribute.

The magnitude of relative importance attributable then becomes the function of the total utility apportioned by the entire respondents. Therefore, the attribute importance is basically the weight $W_{j}$ of each attribute as measured by the respondents. This is stated in Eq. (3), showing $W_{j}$ as the relative importance of attribute $\left(X_{k}\right)$; $\operatorname{Max}\left(\beta_{i j}\right)$ denotes the maximum utility apportioned to the factor (attribute) -the most preferred attribute level). On the contrary, $\operatorname{Min}\left(\beta_{i j}\right)$ represents the minimum utility, which means the least preferred level (Green and Srinivasan, 1978; Kuhfeld, 2005, Orme, 2010).

$$
W_{j}=\frac{\operatorname{Max}\left(\beta_{i j}\right)-\operatorname{Min}\left(\beta_{i j}\right)}{\sum_{j=1}^{t}\left[\operatorname{Max}\left(\beta_{i j}\right)-\operatorname{Min}\left(\beta_{i j}\right)\right]} \times 100
$$

\section{Sampling and data collection}

The respondents in this study were randomly selected and, therefore, a simple random technique (probability sampling) method was utilized. The questionnaire was designed in two forms with both English and Czech format. As with the scope of the study, the emphasis was basically placed on the Czech format. Hence, the English version was given out to our Czech colleague to transcribe the entire questionnaire to a very lucid and understandable Czech language for dissemination to respondents. However, after 
pre-testing the questionnaire, using responses from master students in the Advanced Management and Marketing class, some errors were detected regarding the composition of the translation, questionnaire clarity, thus it was not easily understood (because of some Czech jargon and vocabulary used), since the technique adopted for this study needs to be visibly seen and answered without any form of questioning. In view of the initial setback, the Czech translation was sent to an expert translation here in Zlin known as Zelenka Translation Company for efficient translation.

As a consequence, the full-fledged translation was prepared from an expert translation company. To ensure unnecessary ambiguity of the questionnaire after the expert translation, we pre-tested with a set of Czech students in Management II class with 15 students who originally are Czechs by birth and whose mother tongue and native language is the Czech language. It was, however, undeclared to them that they are answering pre-test questionnaires. This time, the error rate was about 5.6 percent (5.6\%). Even with this meager error rate detected from the pre-test, it was attributed to the scenario combinations (profile set) that was set to be ranked by respondents. This same error rate of $(5.6 \%)$ was also attributed to the fact that some of the students selected for pre-test had to leave for other seminar class leading to uncompleted responses. Data collection took exactly 4 months (Between November- February 2018). Some selected Students at the Tomas Bata University helped in disseminating the questionnaire to other regions in the Czech Republic. It must be noted that some students were originally living in the cities, so it did not pose a problem for them to assist in the research.

Table 2. Respondents and demographic profile

\begin{tabular}{|c|c|c|c|}
\hline \multicolumn{2}{|c|}{$\begin{array}{l}\text { Demographic considerations of the } \\
\text { respondents }\end{array}$} & $\begin{array}{l}\text { Frequencies } \\
\text { (N) }\end{array}$ & $\begin{array}{l}\text { Percentages } \\
(\%)\end{array}$ \\
\hline \multirow[t]{2}{*}{ Gender } & Male & 201 & 46.85 \\
\hline & Female & 228 & 53.15 \\
\hline \multirow[t]{4}{*}{ Age } & $18-25$ & 356 & 83.0 \\
\hline & $26-35$ & 71 & 16.5 \\
\hline & $36-45$ & 2 & 0.50 \\
\hline & $46+$ & 0 & 0 \\
\hline \multirow{4}{*}{$\begin{array}{l}\text { Educational } \\
\text { Background }\end{array}$} & High school & 0 & 0 \\
\hline & Bachelor level & 334 & 42.8 \\
\hline & Master level & 92 & 21.4 \\
\hline & Doctoral level & 3 & 0.80 \\
\hline \multirow{13}{*}{$\begin{array}{l}\text { Respondents located } \\
\text { in the Czech } \\
\text { Republic(Regions) }\end{array}$} & Stredocesky & 18 & 4.20 \\
\hline & Jihocesky & 25 & 5.83 \\
\hline & Plzeňský & 79 & 18.41 \\
\hline & Karlovasrky & 11 & 2.56 \\
\hline & Liberecky & 57 & 13.30 \\
\hline & Kralovehradecky & 3 & 0.68 \\
\hline & Pardubicky & 19 & 48.9 \\
\hline & Vysocina & 23 & 15.1 \\
\hline & Jihomoravsky & 7 & 1.63 \\
\hline & Olomoucký & 67 & 15.62 \\
\hline & Zlinsky & 21 & 24.4 \\
\hline & Moravskoslezský & 19 & 4.43 \\
\hline & Hlavni Mesto Praha & 33 & 7.69 \\
\hline
\end{tabular}


The respondents were selected randomly in the Czech Republic in Table 2. Out of the 531 respondents who received the online questionnaire (designed in Czech), 429 $(80.63 \%)$ gave complete responses and submitted it. In particular, the profile set to be ranked by the respondents were explained to all respondents and tested in the pre-test as earlier indicated. As shown in Table 1, the respondents came from a diverse geosocio demographic background, with a total of 14 regions in the Czech Republic represented in the study. The majority of the respondents representing 99.77 percent $(99.76 \%)$ indicated that they purchase used electronic goods for their personal use and therefore with no intention to sell. In the following section, the steps followed in carrying out the conjoint analysis are explained. Given the proximity and available used goods outlet, the Plzeňský region was the most represented in the study (18.40\%). It can also be seen that the majority of the respondents were within the age bracket of 1825 with a percentage share of 83.0 percent (83.0\%.).

\section{The Conjoint Analysis used in the study}

\section{Stimuli Construction}

The CA approach is sequenced in this manner (Rao, 2014). These are (1) Selection of attributes and respective levels; (2) Generating the profile set to be ranked or rated (3) questionnaire design and (4) the preference modelling. These steps are explained below.

\section{Selection of attributes and levels}

The study settled on five attributes based on literature support and expert knowledge as shown in Table 3. These 5 attributes are Cost Saving (Economic), Brand, Number of years in product use, Risk of product (continued) defect and Product's country of origin. The meaning behind each attribute is briefly explained in Table 3. Subsequently, after determining the attributes, appropriate levels were identified for each attribute as measurable properties relevant for this study.

The 'cost saving' attribute was assigned the levels: Low, Medium and High. The attribute 'Brand', was assigned to levels: Important, Not important and Indifferent. The rest of the attributes were also assigned the following levels. 'Number of years in use': under a year, 1-3 years and more than 4 years; 'Risk of product (continued) defect': Low, Medium and High; and 'Product's country of origin': Not important and Indifferent. These levels attempt to capture the joint effect of a respondent's preference in light of the limited options placed before the respondent to select from. For instance, the levels of Brand explain whether respondents view 'Brand' as "Important", "Not important" or Indifferent" when deciding to purchase used electronic goods online. The levels under each attribute help, especially when respondents are making trade-offs in their selection of profiles placed before them. 
Table 3. Factor preferences in consumer online shopping behaviour for used goods

\begin{tabular}{|c|c|c|}
\hline Attributes & Explanation & Literature support of attributes \\
\hline Cost Saving (Economic) & $\begin{array}{l}\text { The most obvious } \\
\text { consideration for used } \\
\text { products according to most } \\
\text { researchers is economic. } \\
\text { Consumers, therefore, buy for a } \\
\text { fraction of the original price. }\end{array}$ & $\begin{array}{l}\text { Guiot \& Roux (2010); Swan, P. } \\
\text { L.(1972); Leibowitz (1982); Heese et } \\
\text { al. (2005);Anderson\& Ginsburgh } \\
\text { (1994) }\end{array}$ \\
\hline Brand & $\begin{array}{l}\text { This attribute looks at whether } \\
\text { consumers of second-hand } \\
\text { electronic appliances consider } \\
\text { the brand of the product as an } \\
\text { influencing factor. }\end{array}$ & $\begin{array}{l}\text { Degeratu et al. (2000); O'cass \& } \\
\text { Grace (2003);Betts \& Taran (2004); } \\
\text { Clarke (2010) }\end{array}$ \\
\hline $\begin{array}{l}\text { Number of years in product } \\
\text { use }\end{array}$ & $\begin{array}{l}\text { Considers the duration of use } \\
\text { by the first owner before the } \\
\text { product was put on sale. Since } \\
\text { electronic products tend to } \\
\text { fickle out quickly, consumers } \\
\text { would want to the year of } \\
\text { manufacture among others. }\end{array}$ & $\begin{array}{l}\text { Busse et al. (2013); Leismann et al. } \\
\text { (2013) }\end{array}$ \\
\hline $\begin{array}{l}\text { Risk of product (continued) } \\
\text { defect }\end{array}$ & $\begin{array}{l}\text { Explores the risk of purchasing } \\
\text { a defective good either in the } \\
\text { form of manufacturer } \\
\text { refurbished or second goods. }\end{array}$ & $\begin{array}{l}\text { Lee (1998); Gregson \& Crewe } \\
\text { (1998); Pavlou (2003); Wee et al. } \\
\text { (1995); Bian \& Moutinho }(2011)\end{array}$ \\
\hline Product's country of origin & $\begin{array}{l}\text { Examines whether country of } \\
\text { origin of the used electronic } \\
\text { appliance weighs in their online } \\
\text { purchases. }\end{array}$ & $\begin{array}{l}\text { Yu et al. (2013); Van Damme (2014); } \\
\text { Yan et al. (2015); Koschate-Fischer et } \\
\text { al. (2012) }\end{array}$ \\
\hline
\end{tabular}

Source: Authors' results.

\section{Generating the profiles of the attributes}

The traditional conjoint analysis (TCA) approach was used in this study. The TCA approach is multiple regression problem where preference rankings or ratings on a set of stimuli (products) are regarded as observations on the dependent variable. The features of attribute and their respective levels become the observations of the independent variables as earlier stipulated (Orme, 2010). Making use of the experimental design to ascertain the required number of profiles, the fractional factorial design was adhered to instead of a full profile design. The rationale behind this is that, with the full design approach; respondents tend to be burdened creating inconvenience that sometimes result in an unreliable upshot. A typical scenario in this study is that whiles the 5 factors (attributes) at three levels each, amounts to $(3 \times 3 \times 3 \times 3 \times 3)=243$ required sets of profiles. It is somewhat worrisome and impossible to get accurate and dependable responses from respondents when opting for a full design of 243 profiles which will in effect yield accurate results. Hence, to lower the burden on respondents, a smaller but optimized set of profiles is embarked upon in an experimental design (Rao, 2014). Therefore, we opted for a total of 15 profiles in the fractional factorial design in this study. In addition, the study also adopted 'ranking' as the preference scale and 
Monotone Analysis of Variance (MONANOVA) estimation method to generate the partworth utilities. The MONANOVA was ideally chosen because it generates relatively better scores than other part-worth estimation methods (Orme, 2010). In respect of the attributes used in this study, the basic conjoint analysis model is as defined in Eq. (4) below:

$$
Y_{c=} \mu+\beta_{c 1} \text { (Cost saving) }+\beta_{c 2} \text { (Brand) }+\beta_{c 3} \text { (Number of years in product use) }+
$$
$\beta_{c 4}$ (Risk of product (continued) defect) $+\alpha_{c 5}$ (Product's country of origin) $+\varepsilon_{c}$

where the aggregated $\beta^{\prime s}$, the part-worth utilities, become the weights of the attributes. The study made use of XLSTAT software (Addinsoft, 2014) in producing and evaluating the results.

\section{Results and discussion}

An attribute's importance as judged by respondents was computed as the difference between the maximum and the least part-worth utilities for different attributes as expressed in Eq. (3). The part-worth utilities describe an individual respondent's 'value system' or importance assigned to each level in each attribute. These utilities are first computed for each respondent using Eq. (2) and further aggregated and averaged (mean) for all respondents using Eq. (3). Column 7 and 8 in Table 3 show a sample preference ranking order of the 1st and the 429th respondents regarding their utilities assigned to each of the 15 Attributes (Criteria) and Levels with their part-worth utilities relative and importance (Table 4) characteristic profiles they prefer in an ideal used electronic goods online purchase. All the 429 ranked responses regarding the 15 profiles are aggregated to represent the relative importance of each attribute as shown in column 4 of Table 4 . The most preferred levels in criteria are those that receive large part-worth utilities ( ${ }^{*}$ bolded in column 3 of Table 4 ) whiles the least preferred levels acquire small part-worth utilities.

Table 4. Factor (Attributes) and Levels with their part-worth utilities relative and importance

\begin{tabular}{|c|c|c|c|}
\hline Attributes & Levels & $\begin{array}{l}\text { Part-worth utility } \\
\text { (Mean) }\end{array}$ & $\begin{array}{c}\text { Relative importance } \\
(\%)\end{array}$ \\
\hline A1: Cost Saving (Economic) & $\begin{array}{l}\text { Low } \\
\text { Medium } \\
\text { High }\end{array}$ & $\begin{array}{r}\mathbf{1 . 2 7 6 3} \\
-0.0638 \\
-1.2125\end{array}$ & $22.32^{1 s t}$ \\
\hline A2: Brand & $\begin{array}{l}\text { Important } \\
\text { Not important } \\
\text { Indifferent }\end{array}$ & $\begin{array}{r}\mathbf{1 . 2 3 0 5} \\
-0.6683 \\
-0.5622 \\
\end{array}$ & $18.74^{4 t h}$ \\
\hline $\begin{array}{l}\text { A3: Number of years in product } \\
\text { use }\end{array}$ & $\begin{array}{l}\text { under a year } \\
1-3 \text { years } \\
\text { More than } 4 \\
\text { years }\end{array}$ & $\begin{array}{r}\mathbf{1 . 0 9 0 5} \\
-0.3591 \\
-0.7314\end{array}$ & $20.96^{2 n d}$ \\
\hline $\begin{array}{l}\text { A4: Risk of product (continued) } \\
\text { defect }\end{array}$ & $\begin{array}{l}\text { Low } \\
\text { Medium } \\
\text { High }\end{array}$ & $\begin{array}{r}0.0459 \\
-0.3131 \\
\mathbf{0 . 2 6 7 1} \\
\end{array}$ & $17.9^{5 \text { th }}$ \\
\hline A5: Product's country of origin & $\begin{array}{l}\text { Important } \\
\text { Not important } \\
\text { Indifferent }\end{array}$ & $\begin{array}{l}-0.9107 \\
0.4323 \\
\mathbf{0 . 4 7 8 4}\end{array}$ & $20.08^{3 r d}$ \\
\hline
\end{tabular}

Source: Authors' results.

The part-worth and relative importance of the attributes depict respondents' preferred characteristics they wish to see in an online transaction of used electronic 
goods. As shown in Table 4, the respondents adjudged Cost Saving (A1) as the most important factor when buying.

This result affirms what has mostly been written in the literature about the most influential factor for the adoption of used goods. The thrust of this study, however, was to look beyond cost saving (A1) and discover other factors that contribute to consumers' choice for use in electronic goods. In view of this, it can be seen in Table 4 that the next most important factor considered by respondents after cost saving, is the Number of years in product use (A3) representing $20.96 \%$ of the total weights. In this order of attribute importance, Product's country of origin (A5), Brand (A2) and Risk of product (continued) defect (A4) follow in that order of importance as adjudged by consumers of used electronic goods. Further, the results in Table 4 can be demystified to reveal respondents' most preferred characteristic profile of used electronic goods transactions. It can be inferred that respondents' ideal transactional profile regarding second-hand electronic goods, should be one with the following characteristics: a 'low' cost (A11), Brand as an 'important' (A21) feature, the number of years that the product has been used should be 'under a year' (A31), the risk of the product's (continued) defect should be 'medium' and consumers' would be 'indifferent' to a Product's country of origin. This profile setting is achieved after consumers have traded-off several characteristics in a limited attribute-level selection to arrive at this profile. The result of the study is confirmed and authenticated by the R-squared value of 0.989 which points to a high internal consistency in respondents' preferences. With this, it can be concluded that the reliability of the study is intact.

\section{Conclusion}

The continuous growth of the second-hand goods market, especially of electronic gadgets, is largely attributed to the rise in e-commerce sites around the world. Because of the influence of e-commerce sites, second-hand goods that ordinarily used to be traded in open bazaars are now repackaged and sold online around the world. In most countries, local e-commerce sites now offer their platform of services to both used and new products. In all these developments, though tacit knowledge and the literature, both affirm cost saving (price) as the most important factor in most consumer's choice of used goods, there have been very few studies that look beyond price. In particular, there has not been any study that investigates such factors of influence in the light of the growing market of used and refurbished electronic goods as transacted online. This study fills the gap by (1) using an emerging economy (Czech Republic) where used goods outlets are rampant coupled with the propensity for used electronic gadgets; (2) modelling their preferences in a trade-off setting; and (3) reporting on respondents in the Czech Republic considers most important beyond price in their experiences of shopping online for used electronic goods.

In the carefully selected factors (attributes) used in this study, respondents chose 'Number of years in product use' as the next most important factor of consideration when shopping online for used electronic goods. This means that a product's model year and how long the product has been in use is regarded highly ahead of factors such as the country of origin of the product, brand and the risk of purchasing a defective product. The importance of the 'number of years of a product's usage' after 'cost saving (price)' could be explained by how fast electronic product models especially phones, fickle over a period. It can be inferred that most consumers of used electronic goods do not want gadgets that have been excessively used over the period. 


\section{Limitations}

The study has some limitations. In particular, though consumers have weighted the factors that most influence their choices in online purchases of used electronic goods, some of the factors are attributes that the consumer has no control. For instance, Number of years in product use (A3) and risk of product (continued) defect (A4) are attributes that the consumer of used electronic goods would have very little control over when making preferences in product choice. This is because, for some electronic products, it can be difficult in determining how long the product has been in use. Additionally, and in relation to refurbished goods, a consumer would have no control over knowing whether the re-assembled or repaired product would be faulty again. This is where the trade-off modelling made possible by the conjoint analysis method, validates the study, especially in the choice of the attributes. Future work would explore how such factors that the consumer has no control over affect their intention to purchase the used item. Again, the study shed a limitation of not specifying the business model of the second-hand vendors, thus either in the business-to-consumer, businessto-business, consumer-to-business, or consumer-to-consumer type of model. This limitation is partially hinged on the fact that the main analogy of the study was to look beyond price as a motivating factor, as earlier stipulated. However, future research should specify which type of business model in terms of the second-hand model of business.

\section{Acknowledgment}

This paper was supported by the Internal Grant Agency of FaME TBU No. IGA/FaME/2017/006, "Enterprise's Competitiveness Influenced by Consumer Behavior on Traditional and Online Markets."

\section{References}

Addinsoft (2014). XLSTAT 2014, Data analysis and statistics with Microsoft Excel, Paris, France.

Afful-Dadzie, E. and Afful-Dadzie, A., 2017. Open Government Data in Africa: A preference elicitation analysis of media practitioners. Government Information Quarterly.

Anderson, S. P., and Ginsburgh, V. A. (1994), "Price discrimination via second-hand markets", European Economic Review, 38(1), 23-44.

Austin, P. (2015). "Should You Buy Refurbished Electronics?" Consumer Reports. $\begin{array}{lll}\text { Accessed January } & 0518 .\end{array}$ http://www.consumerreports.org/cro/laptops/refurbished-electronics-buyingguide.

Bernoulli, D. (1954), "Exposition of a new theory on the measurement of risk", Econometrica: Journal of the Econometric Society, Vol. 22, No. 2, pp. 23-36.

Bryan, S., and Parry, D. (2002), "Structural reliability of conjoint measurement in health care: An empirical investigation", Applied Economics, Vol. 34, No. 5, pp. 561-567.

Bryan, S., Gold, L., Sheldon, R., and Buxton, M. (2000), "Preference measurement using conjoint methods: An empirical investigation of reliability", Health Econ. Health Economics, Vol. 9, No. 5, pp. 385-395.

Busse, M. R., Knittel, C. R., and Zettelmeyer, F. (2013), “Are consumers myopic? Evidence from new and used car purchases", The American Economic Review, Vol. 103, No. 1, pp. 220-256. 
Churchman, C. W., and Churchman, C. W. (1961), Prediction and optimal decision: Philosophical issues of a science of values. Englewood Cliffs, NJ: Prentice-Hall.

Clarke, A. (2010), The second-hand brand: liquid assets and borrowed goods. Cultures of commodity branding. Leftcoast Press, Walnut Creek, pp. 235-253.

Clerides, S. (2008), "Gains from trade in used goods: Evidence from automobiles", Journal of International Economics, Vol. 76, No. 2, pp. 322-336.

Czaga, P., and Fliess, B. (2004), "Used goods trade: A growth opportunity. Organisation for Economic Cooperation and Development", The OECD Observer, (246/247), 12.

Degeratu, A. M., Rangaswamy, A., and Wu, J. (2000), "Consumer choice behavior in online and traditional supermarkets: The effects of brand name, price, and other search attributes", International Journal of research in Marketing, Vol. 17 No. 1, pp. 55-78.

Equabank (2016). “9 z 10 Čechů prodává či nakupuje zboží z druhé ruky”, The equabank report. Accessed January 11, 2017. https://www.equabank.cz/n/9-z-10-cechuprodava-ci-nakupuje-zbozi-z-druhe-ruky

Fishburn, P. C. (1968), “Utility theory”, Management Science, Vol. 14, No. 5, pp. 335-378.

Ghose, A. (2009), "Internet exchanges for used goods: An empirical analysis of trade patterns and adverse selection", Mis Quarterly, Vol. 33, No. 2, pp. 263-291.

Ghose, A., 2009. Internet exchanges for used goods: An empirical analysis of trade patterns and adverse selection. Mis Quarterly, pp. 263-291.

Green, P. E., and Rao, V. R. (1971), “Conjoint measurement for quantifying judgmental data", Journal of Marketing research, Vol. 8 No. 3, pp. 355-363.

Green, P. E., and Srinivasan, V. (1978), "Conjoint analysis in consumer research: issues and outlook", Journal of consumer research, Vol. 5, No. 2, pp. 103-123.

Green, P. E., Krieger, A. M., and Wind, Y. (2001), "Thirty years of conjoint analysis: Reflections and prospects", Interfaces, Vol. 31, No. 3, pp.56-73.

Gregson, N., and Crewe, L. (1998), "Dusting down second hand rose: Gendered identities and the world of second-hand goods in the space of the car boot sale", Gender, Place and Culture: A Journal of Feminist Geography, Vol. 5, No. 1, pp. 77-100.

Guiot, D., and Roux, D. (2010)', “A second-hand shoppers' motivation scale: Antecedents, consequences, and implications for retailers", Journal of Retailing, Vol. 86 No. 4, pp. 355-371.

Heese, H. S., Cattani, K., Ferrer, G., Gilland, W., and Roth, A. V. (2005), "Competitive advantage through take-back of used products", European Journal of Operational Research, Vol. 164, No. 1, pp. 143-157.

Kogan, K. (2011), "Second-hand markets and intra-supply chain competition”, Journal of Retailing, Vol. 87, No. 4, pp. 489-501.

Koschate-Fischer, N., Diamantopoulos, A., and Oldenkotte, K. (2012), "Are consumers really willing to pay more for a favorable country image? A study of country-oforigin effects on willingness to pay", Journal of International Marketing, Vol. 20, No. 1, pp. 19-41.

Krantz, D. H. (1964), “Conjoint measurement: The Luce-Tukey axiomatization and some extensions", Journal of Mathematical Psychology, Vol. 1, No. 2, pp. 248-277.

Kuhfeld, W. F. (2005), Marketing research methods in SAS. Experimental Design, Choice, Conjoint, and Graphical Techniques. Cary, NC, SAS-Institute TS-722.

Kwarteng, M. A., Pilik, M., \& Jurickova, E. (2017). Mining Interest in Online Shoppers' Data: An Association Rule Mining Approach. Acta Polytechnica Hungarica, Vol. 14, No. 7, pp. 1-15. 
Lee, H. G. (1998). Do electronic marketplaces lower the price of goods? Communications of the ACM, Vol. 41, No. 1, pp. 73-80.

Leismann, K., Schmitt, M., Rohn, H., and Baedeker, C. (2013), "Collaborative consumption: towards a resource-saving consumption culture", Resources, Vol. 2, No. 3, pp. 184-203.

Luce, R. D., and Tukey, J. W. (1964), "Simultaneous conjoint measurement: A new type of fundamental measurement", Journal of mathematical psychology, Vol. 1, No. 1, pp. 1-27.

Malhotra, N. K. (1982), "Structural Reliability and Stability of Nonmetric Conjoint Analysis", Journal of Marketing Research, Vol. 19, No. 2, pp. 199.

Mccullough, J., and Best, R. (1979), "Conjoint Measurement: Temporal Stability and Structural Reliability", Journal of Marketing Research, Vol. 16, No 1, pp. 26-31.

Oraiopoulos, N., Ferguson, M. E., and Toktay, L. B. (2012), "Relicensing as a secondary market strategy", Management Science, Vol. 58, No. 5, pp. 1022-1037.

Orme, B. (2010), Getting Started with Conjoint Analysis: Strategies for Product Design and Pricing Research. Second Edition, Madison, Wis.: Research Publishers LLC.

Pilík, M., Juřičková, E., \& Adu Kwarteng, M. (2017). On-line shopping behaviour in the Czech Republic under the Digital Transformation of Economy. Economic AnnalsXXI, 165.

Rao, V. R. (2014), Applied conjoint analysis, New York, NY: Springer.

Scott, J. E., and Wright, P. (1976), "Modeling an organizational buyer's product evaluation strategy: Validity and procedural considerations", Journal of Marketing Research, Vol. 13, No. 3, pp. 211-224.

Shevlin, B. (2008), "When and How to Use Refurbished Equipment for IT Needs", IT Professional Magazine, Vol. 10, No. 1, pp. 46.

Shulman, J.D. and Coughlan, A.T., 2007. Used goods, not used bads: Profitable secondary market sales for a durable goods channel. Quantitative Marketing and Economics, Vol. 5, No. 2, pp.191-210.

Simon, H. A. (1957), Models of man: social and rational; mathematical essays on rational human behavior in social setting. Wiley. ASIN: B0007ELZJ4.

Singh, S. (2015). "Rise of used goods markets: Why e-commerce companies like OLX, eBay are chasing second-hand goods", The Economic Times. Accessed January 11, 2018. http://economictimes.indiatimes.com/industry/services/retail/riseof-used-goods-markets-why-e-commerce-companies-like-olx-ebay-are-chasingsecond-hand-goods/articleshow/49488856.cms.

Swan, P. L. (1972), "Optimum durability, second-hand markets, and planned obsolescence", Journal of Political Economy, Vol. 80 No.3, pp. 575-585.

Tversky, A. (1967), "A general theory of polynomial conjoint measurement", Journal of Mathematical Psychology, Vol. 4, No. 1, pp. 1-20

Van Damme, I. (2014), Second-Hand Trade and Respectability: Mediating Consumer Trust in Old Textiles and Used Clothing (Low Countries, Seventeenth and Eighteenth Centuries). In Selling Textiles in the Long Eighteenth Century, pp. 193-209, Palgrave Macmillan UK.

Williams, C. C., and Paddock, C. (2003), "The meanings of informal and second-hand retail channels: some evidence from Leicester", The International Review of Retail, Distribution and Consumer Research, Vol. 13, No. 3, pp. 317-336. 